\title{
PELATIHAN PRAKTIKUM IPBA BAGI GURU SMP/SMA DI KOTA SINGARAJA MENUJU OLIMPIADE ASTRONOMI
}

oleh,

Ni Made Pujani dan Ni Ketut Rapi

\begin{abstract}
ABSTRAK
Tujuan pengabdian pada masyarakat ini adalah untuk meningkatkan pengetahuan dan keterampilan praktikum bidang IPBA (Astronomi) bagi guru-guru SMP/SMA di Kota Singaraja dalam rangka mengantisipasi rendahnya prestasi belajar IPBA siswa serta sebagai persiapan menuju olimpiade Astronomi. Sasaran kegiatan adalah guru-guru SMP/SMA yang ada di Kota Singaraja. Realisasi kegiatan dilakukan dengan memberikan ceramah dan pelatihan bertempat di Laboratorium Fisika Dasar Jurusan Pendidikan Fisika FMIPA Universitas Pendidikan Ganesha. Hasil pelatihan menunjukkan bahwa secara umum pelaksanaan pelatihan berjalan baik. Kegiatan pelatihan dapat meningkatkan keterampilan guru dalam melaksanakan praktikum dan mengobservasi objek langit malam; dapat meningkatkan penguasaan materi IPBA dari kategori kurang (rata-rata pre test 47,5) menjadi baik (rata-rata post test 70,5). Demikian pula, respon peserta adalah positif dan guru-guru sangat antusias mengikuti pelatihan. Namun, dalam pelaksanaan praktikum hand on dibutuhkan waktu lebih banyak, sehingga topik pelatihan praktikum perlu dibatasi. Kepada pihak terkait disarankan agar dibentuk suatu wadah dimana para guru dapat sharing pengetahuan tentang pengamatan langit malam dan pembahasan soal-soal terkait dengan olimpiade astronomi.
\end{abstract}

Kata-kata kunci: pelatihan, praktikum, IPBA, Olimpiade Astronomi

\section{Pendahuluan}

Kabupaten Buleleng sebagai salah satu daerah tujuan wisata di Bali, memiliki visi dan misi pembangunan yang berorientasi pada sektor pariwisata, pertanian, pendidikan, dan kesehatan. Pada sektor pendidikan, salah satu misi pembangunan Kabupaten Buleleng adalah menjadikan Buleleng sebagai kota pendidikan. Realisasi dari hal itu telah dituangkan dalam berbagai kebijakan daerah, antara lain dengan memfasilitasi pembangunan lembaga pendidikan mulai dari jenjang taman kanak-kanak (TK) sampai perguruan tinggi (PT).

Berdasarkan hasil survai oleh tim pelaksana, diperoleh gambaran bahwa salah satu permasalahan yang saat ini dihadapi oleh Dinas Pendidikan Kabupaten Buleleng adalah terbatasnya dana untuk melaksanakan program in-service training bagi para guru. Di 
sisi lain, kualifikasi dan profesionalisme para tenaga pendidik (guru) yang ada di Kabupaten Buleleng, khususnya guru bidang studi IPBA di SMP dan SMA banyak yang belum sesuai dengan bidang tugasnya, termasuk pula masih kurangnya kemampuan dan keterampilan-keterampilan profesional guru dalam mengajar IPBA.

Pembelajaran IPBA sebagai bidang studi yang secara formal wajib dibelajarkan pada jenjang pendidikan SMP dan SMA saat ini dihadapkan pada tantangan untuk mampu meningkatkan kualitas proses dan hasil pembelajarannya. Hal ini mengingat bahwa mulai tahun 2005 untuk Astronomi dilombakan dalam ajang bergengsi yaitu pada olimpiade tingkat nasional dan international. Khusus untuk Kabupaten Buleleng, partisipasi di bidang olimpiade Astronomi bagi siswa SMP dan SMA baru mulai tahun 2006, itu pun baru diwakili dari satu sekolah saja yaitu SMA Negeri 1 Singaraja. Dari wakil yang dikirimkan tersebut, belum ada yang bisa menembus hingga lulus di tingkat Propinsi, sebagaimana diinformasikan melalui internet, untuk bidang olimpiade Astronomi belum ada siswa SMP/SMA wakil dari Kabupaten Buleleng atau pun wakil Propinsi Bali yang berhasil meraih medali.

Rendahnya prestasi belajar Astronomi para siswa SMA di wilayah Kabupaten Buleleng tidak terlepas dari kurangnya pembinaan oleh guru (faktor guru) dan karakteristik materi. Dengan berlakunya KTSP mulai tahun 2006, materi IPBA tidak lagi sepenuhnya menjadi suplemen mata pelajaran Fisika tetapi sebagian masuk ke mata pelajaran IPS untuk di SMP dan Geografi untuk di SMA. Sementara itu, untuk membina siswa yang akan mengikuti kegiatan olimpiade umumnya ditugaskan kepada guru Fisika. Di sini timbul kesenjangan di mana para guru yang tidak mengajar Astronomi ditugaskan membina siswa untuk mengikuti olimpiade Astronomi. Oleh karena itulah sangat diperlukan adanya pembinaan yang berkelanjutan kepada guru IPA di SMP dan guru Fisika di SMA agar mereka memiliki kemampuan yang memadai untuk membina calon peserta olimpiade Astronomi. Dinas Pendidikan bersama-sama dengan seluruh SMP/SMA yang ada di Kabupaten Buleleng harus sesegera mungkin melakukan persiapan pembinaan bidang IPBA (Astronomi) yang terprogram dan kontinu untuk menghadapi pelaksanaan Olimpiade Astronomi Nasional/Internasional tahun 2012.

Secara alamiah Astronomi memiliki konsep pemikiran dan pemahaman yang terintegrasi secara simultan baik dalam perkembangan ilmunya, teknologinya, terapan teknisnya, maupun pendidikannya. Dalam hal ini, Astronomi dan IPA/Fisika merupakan 
materi pelajaran di SMP/SMA yang terpadu secara integral, di mana konsep-konsep Astronomi melibatkan konsep-konsep Fisika. Konsekwensinya, keberhasilan siswa dalam pelajaran Astronomi dipengaruhi oleh kemampuannya dalam menerapkan konsep-konsep Fisika yang relevan ke bidang studi IPBA. Hal ini pula yang dijadikan sebagai acuan, di mana dalam kurikulum, materi Astronomi seharusnya menjadi bagian dari mata pelajaran fisika, sehingga pengajar Astronomi di SMP/SMA umumnya adalah guru IPA/Fisika.

Namun demikian, walaupun ada jalinan yang terintegrasi antara Fisika dengan Astronomi, dampak dari hal ini adalah ada kecendrungan belum mapannya penguasaan materi Astronomi tersebut oleh guru Fisika karena Astronomi memerlukan pemahaman tersendiri dan cakupan materimya sangat luas. Di samping adanya pergeseran orientasi konten kurikulum dari Fisika ke IPS dan Geografi. Mengingat ketidak sesuaian kualifikasi guru Astronomi dengan bidang keahliannya itu, maka kualitas penguasaan guru dalam bidang Astronomi harus ditingkatkan, sehingga mereka menjadi tenaga guru yang terampil dalam mengelola pembelajaran. Salah satu alternatif yang dipandang cukup visibel untuk dilakukan adalah melalui penyegaran akademis (refreshing program) yang inti kegiatannya meliputi pelatihan merancang dan melaksanakan praktikum IPBA bidang Astronomi. Melalui program ini, guru diharapkan memperoleh "sesuatu" yang baru dan dapat dijadikan sebagai acuan dalam pengembangan tugas dan profesinya yang nantinya secara langsung dapat meningkatkan produktivitas kerjanya seperti, mampu memberikan pembinaan di bidang IPBA bagi anak didiknya menuju olimpiade Astronomi. Bila kualitas pengetahuan guru meningkat akan berimplikasi pada kualitas pelaksanaan PBM, dan akhirnya bermuara pada peningkatan prestasi bidang Astronomi.

Hasil penelitian terdahulu yang dilakukan oleh Averch et.al,1984 dan Jamison,1974 (dalam Wirta, 1990) menemukan bahwa pengaruh variabel kualitas guru cukup efektif terhadap prestasi belajar yang dicapai siswanya. Dalam pembelajaran IPA di SD se Kabupaten Buleleng, hasil penelitian Wirta, dkk (1990) menemukan bahwa terdapat hubungan yang positif dan bermakna antara kualitas guru dengan prestasi belajar siswanya. Khusus dalam kegiatan praktikum IPBA, hasil penelitian Pujani (2010) menemukan bahwa pembekalan keterampilan laboratorium IPBA (Kebumian) bagi calon guru fisika dapat meningkatkan keterampilan calon guru dalam merancang, 
melaksanakan dan melaporkan praktikum IPBA. Untuk bidang Astronomi capaian keterampilan laboratorium yang dicapai calon guru cenderung lebih rendah dari capaian keterampilan laboratorium Kebumian (Pujani, 2011).

Masalah-masalah di atas bukan saja dihadapi dan dialami oleh guru IPBA di Kabupaten Buleleng yang baru bertugas dengan masa kerja kurang dari 5 tahun, tetapi guru yang sudah berpengalaman mengajar lebih dari 10 tahun pun mengalami hal yang sama. Menyadari demikian urgennya persoalan tersebut, maka dalam rangka pengabdian masyarakat Universitas Pendidikan Ganesha Singaraja, persoalan menyangkut peningkatan wawasan dan kemampuan guru dalam bidang praktikum IPBA (Astronomi), khususnya pada jenjang SMP/SMA sangat layak untuk dijadikan sebagai salah satu tema atau fokus kegiatan, bagi perbaikan kualitas proses dan produk pendidikan pada level SMP/SMA melalui refreshing program bagi guru-guru IPA/Fisika pada SMP/SMA di Kota Singaraja.

Berdasarkan uraian masalah di atas, maka permasalahan pokok yang hendak diurai melalui program ini adalah: "Bagaimanakah cara meningkatkan kualitas keterampilan praktikum bidang IPBA (Astronomi) bagi guru-guru SMP/SMA di Kota Singaraja dalam rangka mengantisipasi rendahnya prestasi belajar IPBA siswa serta sebagai persiapan menuju olimpiade Astronomi. Adapun tujuan kegiatan ini adalah untuk meningkatkan pengetahuan dan keterampilan praktikum bidang IPBA bagi guru-guru SMP/SMA di Kota Singaraja dalam rangka mengantisipasi rendahnya prestasi belajar IPBA siswa serta sebagai persiapan menuju olimpiade Astronomi.

Manfaat dari kegiatan ini adalah (1) Pemerintah Kabupaten Buleleng, khususnya Dinas Pendidikan Kabupaten Buleleng, bahwa program ini dapat membantu merealisasikan salah satu program yang telah disusun dalam rencana pembangunan pendidikan di Buleleng, Provinsi Bali, khususnya pada jenjang SMP/SMA, yaitu peningkatan pengetahuan dan keterampilan guru dalam melakukan kegiatan-kegiatan akademis untuk mendukung tugas-tugas profesionalnya, sehingga secara langsung berdampak bagi peningkatan produktivitas pendidikan di Kota Singaraja.(2) Guru-guru SMP/SMA di Kota Singaraja, program ini sangat bermanfaat dalam meningkatkan kualitas penguasaan bidang Astronomi sehingga nantinya mereka dapat memiliki keterampilan melaksanakan praktikum Astronomi yang memadai megingat pengajar Astronomi umumnya adalah guru fisika, serta mampu membina siswa dalam persiapan 
menghadapi olimpiade Astronomi. (3) Universitas Pendidikan Ganesha, program ini sangat bermanfaat dalam menjalin kerjasama yang mutualis antara LPTK dengan kalangan masyarakat luas, sehingga tenaga dan berbagai potensi yang ada dapat disumbangkan kepada khalayak luas, khususnya yang berkenaan dengan sektor pendidikan.

\section{Metode Pelaksanaan Pengabdian}

Kerangka pemecahan masalah yang dikembangkan diawali dengan kegiatan orientasi lapangan oleh tim pelaksana. Masalah yang ada di lapangan kemudian diidentifikasi sehingga ditemukan ada masalah yang perlu mendapat penanganan yaitu ketidak sesuaian kualifikasi guru IPBA dengan materi yang diajar merupakan salah satu penyebab ketidak berhasilan pembinaan bidang Astronomi pada siswa SMP/SMA di Kota Singaraja. Setelah itu dilakukan pengkajian literatur, ditemukan alternatif yang visibel untuk dilaksanakan yaitu melalui program refreshing berupa pemberian pelatihan bidang Astronomi untuk meningkatkan kualitas penguasaan guru. Penyegaran materi dilakukan dengan ceramah/presentasi dan praktikum/observasi yang diharapkan dapat meningkatkan kemampuan/pemahaman guru tentang Astronomi. Materi yang dipraktikumkan disesuaikan dengan tuntutan olimpiade Astronomi bidang praktikum/observasi.

Program ini dirancang sebagai bentuk jawaban dan antisipasi dari berbagai permasalahan menyangkut kualitas dan kinerja guru SMP/SMA di Kota Singaraja, khususnya pada bidang peningkatan kualitas guru yang saat ini tengah berkonsentrasi pada pembangunan berbagai institusi pendidikan dan tenaga kependidikan di berbagai pelosok wilayahnya. Berangkat dari rasional tersebut, maka program ini akan dilaksanakan dengan menyelenggarakan pelatihan untuk meningkatkan kualitas penguasaan bidang IPBA bagi guru-guru SMP/SMA di Kota Singaraja. Model pelaksanaan kegiatan ini akan dilakukan secara langsung (tatap muka) dengan bidang kajian yang terkonsentrasi pada 2 (dua) topik dasar materi yaitu, (1) Pembekalan tentang kompetensi yang diperlukan guru dalam praktikum IPBA (Astronomi) dan Cara Mengenali/Mengamati Objek Menarik Langit Malam, dan (2) Pelatihan praktikum IPBA secara hand on dan observasi lapangan. 
Lama pelaksanaan kegiatan adalah 2 (dua) hari dengan melibatkan perwakilan guru SMP/SMA yang ada di Kota Singaraja. Setelah diberi pembekalan materi, setiap kelompok peserta dilatih melaksanakan praktikum dengan menggunakan alat-alat praktikum sederhana dan melakukan pengenalan teleskop untuk mendukung pengamatan/observasi langit malam. Diakhir pelatihan, peserta diberi tes untuk mengetahui penguasaan materi dan keberhasilan program. Melalui sejumlah kegiatan tersebut, diharapkan para guru SMP/SMA memperoleh penyegaran wawasan dan peningkatan kualitas pengetahuan serta keterampilan melakukan praktikum bidang Astronomi untuk kepentingan tugas dan profesinya sebagai pengembang dan pelaksana kurikulum.

Khalayak sasaran antara yang strategis dalam kegiatan ini adalah para guru SMP/SMA di Kota Singaraja. Di sisi lain, permasalahan mendasar dan aktual yang terjadi pada sektor pendidikan di Kabupaten Buleleng adalah rendahnya prestasi belajar IPBA siswa SMP/SMA serta sebagai persiapan pembinaan menuju olimpiade Astronomi. Permasalahan ini salah satunya disinyalir dapat diantisipasi dan dieliminir melalui peningkatan kualitas penguasaan bidang IPBA bagi guru SMP/SMA, sehingga sejak awal guru dapat mempersiapkan dan mengelola proses belajar mengajar dengan lebih baik. Berdasarkan rasional tersebut, maka sasaran yang dipilih dipandang cukup visibel dan prediktif bagi penyebarluasan informasi atau hasil dari kegiatan ini secara berkelanjutan dan terstruktur

Jumlah guru yang akan dilibatkan adalah sebanyak 20 orang guru yang mengajar IPBA (guru IPA dan Fisika) berasal dari 10 sekolah SMP/SMA yang ada di Kota Singaraja. Penentuan subjek didasarkan pada proporsi jumlah guru per jenjang sekolah. Kegiatan pelatihan ini dilaksanakan dengan sistem kader. Guru SMP/SMA perwakilan yang ditunjuk akan diberikan pelatihan. Mereka yang dijadikan kader dipersyaratkan agar mampu dan mau bekerja sama, serta dapat menyebarkan hasil kegiatan kepada guru lainnya

Pola dan tahapan evaluasi akan disesuaikan dengan metode yang digunakan dalam upaya mencapai tujuan. Beberapa metode yang akan digunakan dalam kegiatan P2M ini adalah presentasi, diskusi dan observasi/pengamatan langit malam Astronomi sederhana. Setiap metode dipilih sesuai dengan relevansinya terhadap pencapaian tujuan. Adapun rincian metode yang digunakan adalah sebagai berikut. 
Tabel 1 Metode Pelaksanaan

\begin{tabular}{|l|l|}
\hline \multicolumn{1}{|c|}{ Metode Pelaksanaan } & \multicolumn{1}{c|}{ Tujuan yang ingin dicapai } \\
\hline Presentasi & $\begin{array}{l}\text { Untuk memberi pengertian tentang kompetensi yang } \\
\text { diperlukan guru dalam praktikum IPBA (Astronomi) } \\
\text { dan Cara Mengenali/Mengamati Objek Menarik } \\
\text { Langit Malam. }\end{array}$ \\
\hline Diskusi & $\begin{array}{l}\text { Untuk memantapkan pemahaman peserta terhadap } \\
\text { materi yang dibahas }\end{array}$ \\
\hline Praktikum/Observasi & $\begin{array}{l}\text { Untuk melatih keterampilan guru dalam melaksanakan } \\
\text { praktikum Astronomi khususnya melakukan observasi } \\
\text { terhadap objek langit malam, serta dapat } \\
\text { melaksanakan praktikum Astronomi dengan alat-alat } \\
\text { sederhana secara hand } \text { on dengan topik seperti: jam } \\
\text { matahari, rotasi dan revolusi bumi, rotasi dan revolusi } \\
\text { bulan, tata koordinat dan pengenalan rasi bintang. }\end{array}$ \\
\hline Tes & $\begin{array}{l}\text { Pre test dan post test diberikan untuk memberi } \\
\text { wawasan tentang materi IPBA dan mengukur } \\
\text { ketercapaian program. }\end{array}$ \\
\hline
\end{tabular}

Sesuai dengan metode kegiatan di atas, maka evaluasi akan dilaksanakan pada awal, akhir dan selama pelaksanaan kegiatan (directed evaluation/ proccess evaluation). Indikator yang digunakan sebagai parameter keberhasilan program ini adalah, "terjadinya peningkatan penguasaan materi dan meningkatnya kemampuan guru dalam melaksanakan praktikum astronomi dengan alat-alat sederhana secara hand on dan dalam mengobservasi objek langit malam dengan menggunakan teleskop." Untuk itu, di awal dan di akhir kegiatan akan diberikan tes materi IPBA (Astronomi) dan tim tutor akan mendampingi guru-guru saat pelatihan praktikum dengan alat-alat sederhana maupun dengan menggunakan teleskop untuk mengobservasi objek menarik di langit malam.

\section{Hasil dan Pembahasan}

Pada bagian ini dipaparkan tentang hasil atas perlakuan yang diberikan untuk memecahkan masalah yang dihadapi oleh masyarakat dan pembahasannya. Pelatihan praktikum Astronomi bagi guru SMP/SMA di Kota Singaraja ini, dilaksanakan tanggal 6-7 Oktober 2012, bertempat di Laboratorium Jurusan Pendidikan Fisika FMIPA Universitas Pendidikan Ganesha. Panitia mengundang 20 orang guru-guru SMP/SMA dari 10 sekolah di Kota Singaraja melalui kepala sekolah masing-masing. Penunjukan peserta diserahkan kepada kepala sekolah, disarankan agar guru yang ditunjuk adalah 
yang membina siswa dalam olimpiade Astronomi masing-masing sebanyak 2 orang. Dari 20 orang guru yang diundang, ternyata jumlah guru yang hadir hanya 8 orang, tetapi dilihat dari jumlah sekolahnya, dari 10 sekolah yang diundang ada sekitar $80 \%$ sekolah yang mengirim wakilnya. Ketidak hadiran sebagian guru-guru disebabkan Kepala Sekolah hanya menugaskan 1 orang guru saja, karena ada beberapa kegiatan kompetisi yang waktunya bersamaan. Hal ini menunjukkan bahwa respon sekolah terhadap pelatihan yang dilaksanakan adalah positif.

Pengetahuan awal peserta pelatihan tentang praktikum IPBA terkait dengan praktikum/observasi langit malam (sesuai soal olimpiade) sangat beragam, ada yang sudah punya cukup pengalaman, beberapa sudah pernah mencoba-coba, tetapi kebanyakan guru SMP/SMA belum memahami penggunaan teropong dan belum mengenali objek yng akan diamati dalam observasi/praktikum Astronomi. Melihat kondisi ini, pelatihan diawali dengan mengenalkan beberapa kompetensi praktikum yang perlu dimiliki guru dan pengenalan objek menarik langit malam, agar nantinya guru dapat malakukan praktikum/observasi secara benar. Setelah cukup barulah kegiatan dilanjutkan dengan pelatihan praktikum/observasi. Dengan pola seperti ini, pemahaman guru terhadap teknik mengobservasi objek langit mengalami peningkatan, di mana guru dapat mengenali berbagai objek langit malam seperti bintang paling terang, mengenal berbagai rasi, planet, mengenal bintang penanda arah (salib selatan) dan penanda musim (scorpio dan orion). Terhadap praktikum secara hand on dengan alat-alat sederhana, kegiatan praktikum belum dapat dilakukan dengan baik karena kekurangan waktu. Kegiatan ini akhirnya dilakukan dengan mendiskusikan petunjuk praktikum yang sudah disiapkan, dan mempraktekkan cara pengamatan fasa bulan saja.

Sementara itu, penguasaan terhadap materi IPBA digali melaui pre test dan post test yang diberikan di awal dan di akhir pelatihan. Skor yang diperoleh ditampilkan pada Tabel 2 berikut.

Tabel 2 Capaian skor pretes dan postes tentang penguasaan materi IPBA

\begin{tabular}{|c|l|l|l|l|l|}
\hline Kode Guru & Asal Sekolah & Pretes & Postes & Gain & Keterangan \\
\hline A & SMP N 2 Singaraja & 40 & 65 & 25 & Meningkat \\
\hline B & sda & 45 & 68 & 23 & Meningkat \\
\hline C & SMPN 4 Singaraja & 40 & 68 & 28 & Meningkat \\
\hline D & SMP Lab Undiksha & 45 & 68 & 23 & Meningkat \\
\hline
\end{tabular}




\begin{tabular}{|c|l|l|l|l|l|}
\hline E & SMAN 1 Singaraja & 60 & 75 & 15 & Meningkat \\
\hline F & SMAN 2 Singaraja & 50 & 70 & 20 & Meningkat \\
\hline G & SMAN 4 Singaraja & 45 & 75 & 30 & Meningkat \\
\hline H & SMA Lab Undiksha & 55 & 75 & 20 & Meningkat \\
\hline Rata-rata & & 47,5 & 70,5 & & \\
\hline Kategori & & Kurang & Baik & & \\
\hline
\end{tabular}

Berdasarkan Tabel 2, tingkat kemampuan guru dalam astronomi tergolong masih kurang $(47,5)$. Setelah pelatihan capaiannya mengalami peningkatan dengan rata-rata sebesar 70,5 dengan kategori baik. Hal ini menunjukkan bahwa penguasaan materi Astronomi guru-guru mengalami peningkatan.

Berdasarkan capaian di atas, secara umum dapat dikatakan bahwa pelaksanaan pelatihan berjalan baik, dapat memberi manfaat yang besar bagi para guru SMP/SMA, serta tepat sasaran. Hal ini terlihat dari respon peserta yang begitu antusias mengikuti pelatihan. Pada hari I, guru dengan penuh perhatian mengikuti presentasi tentang Kompetensi yang diperlukan guru dalam praktikum dilanjutkan dengan pengenalan objek menarik di langit malam. Diskusi berkembang hingga para guru merasa cukup memiliki pemahaman tentang praktikum yang dilatihkan. Guru sangat antusias mendengarkan paparan dari pemakalah, Dr. Ni Made Pujani, M.Si dan Nyoman Suwitra, M.S dari Jurusan Pendidikan Fisika Undiksha.

Pada hari II, guru dengan penuh semangat ingin berlatih melakukan praktikum hand on yang telah disiapkan, mencoba mengoperasikan teleskop dan melakukan pengamatan langit malam. Pada siang hari kegiatan pengamatan langit malamnya dapat dilakukan dengan software "Stelarium". Sementara itu pelatihan praktikum secara hand on hanya disample untuk topic tertentu saja, karena kendala waktu.

Respon yang positif dari para guru untuk mengikuti pelatihan praktikum IPBA menuju olimpiade Astronomi bagi guru-guru SMP/SMA di Kota Singaraja menunjukkan bahwa kemampuan dan keterampilan guru dalam melakukan praktikum IPBA memang sudah merupakan kebutuhan mendesak. Diadakannya olimpiade Astronomi seiap tahun sekali menyebabkan para guru harus mampu mengikuti perkembangan keilmuan itu sendiri agar mampu memberikan yang terbaik bagi sekolah dan siswanya. Fasilitas laboratorium yang tersedia di sekolah-sekolah akan dapat dimanfaatkan secara lebih optimal bila didukung oleh kemampuan SDMnya. Dengan kemampuan melakukan praktikum, menggunakan teleskop, dengan penguasaan materi dan pengetahuan mengenai langit malam, serta dengan pemahaman mengenai teleskop, para guru akan dimudahkan dalam menyiapkan siswanya menghadapi olimpiade astronomi. Demikianpun, sekolah akan dapat keuntungan karena memiliki guru yang terlatih.

Di sisi lain, dengan kemampuan yang dimiliki guru dalam melakukan praktikum, diharapkan dapat mendorong para guru untuk aktif meneliti. Hal ini akan berdampak positif kepada siswa karena guru akan selalu memberikan pengalamannya yang terbaik bagi para siswa. Guru akan terbiasa meneliti dan berdampak positif pada pembimbingan 
siswa dalam menyusun karya ilmiah untuk kegiatan lomba-lomba ilmiah Dengan demikian suasana atmosfer di sekolah-sekolah akan menjadi kondusif. Mudah-mudahan bentuk pengabdian yang kami laksanakan ini dapat memotivasi guru untuk berani meneliti karena kemampuan meneliti juga merupakan bagian dari peningkatan profesionalisme guru.

Berdasarkan kondisi itu dapat dikatakan bahwa pelatihan ini dapat menambah wawasan dan keterampilan para guru dalam memanfaatkan alat-alat sederhana untuk melakukan praktikum astronomi maupun untuk mengobservasi objek langit malam. Hal ini didukung pula dari hasil pemantauan tim tutor yang mendampingi peserta selama pelatihan, dan respon positif yang diberikan oleh peserta melalui angket sederhana yang disebarkan tim pelaksana.

\section{Penutup}

Pelatihan praktikum IPBA bagi guru SMP/SMA merupakan kebutuhan yang mendesak bagi sekolah, terlebih dengan adanya olimpiade Astronomi. Untuk mengantisipasi kebutuhan ini pelatihan praktikum untuk mengobservasi langit malam merupakan alternatif yang tepat agar para guru dapat menyiapkan siswanya lebih dini dslam menghadapi olimpiade. Secara lebih rinci dapat dsimpulkan bahwa: (1) Pelatihan praktikum IPBA bagi guru SMP/SMA meningkatkan keterampilan guru-guru SMP/SMA di Kota Singaraja dalam melakukan praktikum dan mengobservasi langit malam. (2) Pelatihan praktikum IPBA bagi guru SMP/SMA meningkatkan penguasaan materi IPBA (pre test $=47,5$, post test $=70,5$ ) sehingga memudahkan guru dalam membina siswa peserta olimpiade astronomi. (3) Respon guru-guru SMP/SMA di Kota Singaraja terhadap pelaksanaan pelatihan praktikum IPBA bagi guru SMP/SMA adalah positif.

Berdasarkan pembahasan kendala-kendala yang dihadapi dalam pelatihan ini, maka dapat disarankan kepada (1) tim pelaksana, agar melakukan koordinasi dengan Kepala Sekolah sehingga pelaksanaan kegiatan pelatihannya tidak berbenturan dengan kegiatan lainnya, sehingga makin banyak guru-guru yang dapat berpartisipasi. (2) pihak terkait, seperti LPM Undiksha, Dinas Pendidikan Kabupaten Buleleng, dan sekolah (SMP/SMA), agar menyelenggarakan pelatihan lanjutan agar keterampilan yang sudah dimiliki para guru dapat dikembangkan. Pelatihan yang sejenis agar diselenggarakan 
untuk para guru lainnya dan perlu dibuatkan suatu wadah dimana para guru dapat sharing pengetahuan tentang pengamatan objek langit malam.

\section{DAFTAR PUSTAKA}

Pujani. N.M. 2010. Pembekalan Keterampilan Laboratorium Kebumian Berbasis Kemampuan Generik Sains Bagi Calon Guru Fisika. Laporan Hasil Penelitian, Hibah Disertasi Doktor, Tidak dipublikasi. LPPM UPI, Bandung.

Pujani, N.M. 2011. Pembekalan Keterampilan Laboratorium IPBA Berbasis Kemampuan Generik Sains Bagi Calon Guru. Disertasi Doktor. Tidak dipublikasi. UPI, Bandung.

Pujani, N.M., dan Liliasari. (2011). Deskripsi Hasil Analisis Pembelajaran IPBA sebagai Dasar Pengembangan Kegiatan Laboratorium Bagi Calon Guru. Makalah pada Seminar Nasional Pendidikan FKIP Unila, Bandar Lampung. 29-30 Januari 2011.

Suastra dan Made Pujani. 1999. Pengembangan Alat-alat Percobaan Sederhana Buatan Guru sebagai Upaya Meningkatkan Proses dan Hasil Belajar Siswa Kelas I SLTP N 6 Singaraja. Laporan Hasil Penelitian Tindakan Kelas, DIKS STKIP Singaraja.

Wirta, M., Ketut Suma, Wayan Santyasa, Made Pujani, Ketut Rapi. 1990. Prestasi Belajar IPA Siswa Kelas VI SD Negeri se Kabupaten Buleleng tahun Ajaran 1990/1991 Sebagai Fungsi Kualitas Reinforcement dan Kualitas Guru. Laporan Penelitian. Denpasar: Universitas Udayana. 